\title{
How to Cultivate Students' Creative and Innovative Ability in Art and Design Teaching of Colleges
}

\author{
Yonghua Jing \\ Minsheng College \\ Henan University \\ Kaifeng, Henan, China 475004
}

\begin{abstract}
With the continuous development and innovation of cultural and creative industries, we are looking forward the upgrade and transformation of art and design education in colleges and universities. In the teaching of art and design teaching, the cultivation of innovative ability is the core. At present, many colleges and universities in China generally attach no importance to innovation but skills in their art and design teaching, resulting in prominent homogenization in art and design. We must pay attention to the cultivation of students' innovative ability in our art and design teaching. Based on this, the paper proposed the following measures for learning and communication with fellows.
\end{abstract}

Keywords-innovative ability; art and design; colleges and universities; strategy

\section{INTRODUCTION}

The development of society needs innovation, and the further enhancement of China's economic strength needs creative talents. In the art and design teaching of colleges and universities, our primary task is the cultivation of students' innovative ability. The headspring of art and design is of innovation, and from the current status of art and design teaching in China, widespread deficiencies exist in the cultivation of students' innovative ability. Therefore, the exploration of innovative ability cultivation ideas has a very important significance for enhancing the quality of design talent and completing art and design teaching system.

\section{Establish TeAChING Platform Centered ON INNOVATION}

The cultivation of talents in colleges is mainly implemented through teaching process. Establishing teaching platform centered on innovation is to base on the actual characteristics of students, teach students in accordance of their aptitude, choose targeted teaching methods and furthest arouse the desire of students for innovation and make the innovative ability of students in art and design major further improved.

\section{A. The Premise of Cultivating the Innovative Ability of} Students Is to Improve Their Initiative in Learning

In the process of teaching art and design, the teacher should make efforts to create the situation of innovation, implement the model of teaching of innovative design and cultivate the consciousness of innovation of students through intensive training for their divergent thinking. Only through fully arousing students' enthusiasm of learning can the teacher improve students' innovative ability and arouse their enthusiasm for creation and let students quickly enter into the spirit of a creative character. The teacher should encourage students to voice their opinions, boldly query to gradually cultivate their consciousness of innovation. Meanwhile, they should teach students in accordance of their aptitude and respect the individual differences of students, insist on the policy of quality-oriented education and keep the thought of students active to improve the initiative of learning.

\section{B. The Basic Condition of Cultivating Students' Innovative Ability Is to Improve Teachers' Consciousness of Innovation}

In teaching process, the premise of cultivating innovative ability of students in art and design major is that the teacher has certain consciousness of innovation. In design teaching, the teacher should abandon the authority, focus on training students' habit of query and encourage students to autonomously find the problem and think independently. At the same time, the teacher should also encourage students' individuality and independence and encourage them to dare to be the first and have the thinking of artistic innovation. Only through continuously improving the innovative ability of their own can teachers cultivate students who have innovative ability.

\section{The Important Means of Cultivating Students' Innovative Ability Is to Create Good Innovation Atmosphere}

The precondition of sparking students' inspirations and giving play to their creativity is to create positive, aggressive, harmonious and relaxed atmosphere. In teaching process, the teacher should make efforts to create a positive cultural atmosphere and arouse students' desire of creation. The school should consciously create the atmosphere of art and design innovation and cultivate students' creative ability and sense of participation. Schools can open second classroom, start from students' interests and hobbies and organize various learning activities to provide the platform of practice 
and innovation for students and furthest arouse students' innovative thinking.

\section{OPTIMIZE THE CURRICULUM PROVISION OF ART AND DESIGN MAJOR}

The curriculum provision of art and design major must walk in the frontier of discipline and specialty and organically combine theoretical knowledge with practical demands to meet the requirements of current social development. With the creative industry that develops rapidly, its development also presents the tendency of integration and diversification. The development of creative industry integrates many core factors of production. It requires that the curriculum provision of art and design major in colleges should organically integrate professional knowledge of multiple disciplines. Because the art and design major has the interdisciplinary and comprehensive characteristics, in teaching process, the teacher should continuously adjust and optimize the teaching contents and major courses, pay attention to the intersectionality and integration of discipline and continuously expand art and design education to the fields of other disciplines through mutual penetration with other disciplines.

At present, the teaching contents and educational curriculum of art and design in many colleges and universities still follow the teaching methods of traditional drawing major and mainly refer to the model of teaching of other countries. Teachers pay no attention to the teaching of engineering discipline and only teach some knowledge about the principle of professional design and the development of formal beauty, so that it causes relatively low quality of teaching in basic design course. After graduation, some students create works with simple structure and single product function. They cannot keep pace with the times as well as meet the requirements of actual development of the society. Therefore, in order to further improve the practicality of art and design education in colleges and universities, it is necessary to optimize and adjust the teaching contents and teaching course system of art and design, pay high attention to the relevance between correlated curriculums, properly add the practical teaching courses and emphasize the cultivation of applied and professional talents.

\section{Strengthen The Link OF PRactical Teaching}

Because of having very strong applicability, in order to better complete the objective of talents training, art and design major in colleges and universities must strengthen the link of practical teaching and better cultivate students' innovative ability. In practical teaching, the teacher can choose some targeted topic projects for students to make market survey on the basis of learning theoretical knowledge; and then organize students to design some feasible topics; carry out various forms of task activities of "college students' innovation", encourage students to actively participate in and let them design independently according to topic projects. In this way, it can not only cultivate students' spirit of innovation and innovative ability, but also promote the development of students' personality and further improve comprehensive quality of students.

\section{CONCLUSION}

As a systematic engineering, cultivating the innovative ability of students in art and design major needs the joint efforts of many aspects. Colleges and universities should establish feasible system, regard innovation as the soul, and guarantee the implementation of training program of innovative talents to cultivate more art and design talents for our country with spirit of innovation.

\section{REFERENCES}

[1] Luo Xiaocong. Cultivation and Education of Art and Design Talents [J], Education and Vocation, 2015(14)

[2] Chen Hong. How Art and Design Major in Colleges in the New Era to Carry out Innovative Education [J], Popular Literature, 2014(22)

[3] Liu Zhi, Zhang Zongdeng, Yang Yongbo, Tian Fei. Research on Entrepreneurial Practice of Independent Innovation of Students in Art and Design Major-Take Hunan University of Technology as an Example [J], Journal of Central South University of Forestry and Technology (social science edition), 2014(04). 